\title{
Long-Term Ultraviolet A Eye Irradiation Causes Retina Denaturation in Mice
}

\author{
Keiichi Hiramoto Yurika Yamate Eisuke F. Sato \\ Department of Pharmaceutical Sciences, Suzuka University of Medical Science, Suzuka, Japan
}

\begin{abstract}
What Is It about?
Mice that received ultraviolet (UV) A eye irradiation for 12 months suffered marked retina denaturation. The expression of inducible nitric oxide synthase (iNOS), matrix metalloproteinase-2 (MMP-2), MMP-9, and vascular endothelial growth factor in UVA eye irradiation mice was significantly higher than in control mice. Furthermore, following UVA eye irradiation, the expression of $\beta$-amyloid and macrophages was increased. In addition, the increase in these parameters observed due to denaturation was not seen in iNOS knockout mice. These results indicate that long-term UVA eye irradiation induces retina denaturation and that this phenomenon is similar to age-related macular degeneration.
\end{abstract}

\section{Keywords}

Ultraviolet A radiation · Matrix metalloproteinase $\cdot$ Macrophage

\section{Abstract}

Background: Long-term ultraviolet (UV) A eye irradiation in mice initiates the induction of photoaging. However, the changes in the eye due to long-term exposure to UVA radiation are still unclear. Methods: Male C57BL/6j (control) and inducible nitric oxide synthase knockout (iNOS ${ }^{-1-}$ ) mice were used in this study. The eyes of the mice were locally exposed to UVA radiation for 12 months. Results: The expression of iNOS, matrix metalloproteinase-2 (MMP-2), MMP-9, vascular endothelial growth factor, $\beta$-amyloid, and macrophages in the retina all increased after UVA irradiation. Furthermore, in the iNOS ${ }^{-/-}$mice, no retinal changes were induced by UVA eye irradiation. Conclusions: These results indicated that long-term UVA eye irradiation led to iNOS-induced denaturation of the retina; however, further studies are needed to confirm these findings.

(c) 2017 The Author(s)

Published by S. Karger AG, Basel 


\section{Introduction}

When the skin or eyes are exposed to ultraviolet (UV) radiation, damage occurs in the exposed areas. With short-term exposure of the skin, UVB radiation causes sunburn and UVA radiation causes suntan. In addition, UV radiation induces photoimmunosuppression and reduces the resistance of the human body. Many reports have suggested potential mechanisms underlying the activity of short-term UV radiation, such as via the production of active oxygen and cytokines by irradiation [1-4]. With long-term exposure of the skin, UV radiation induces skin cancer and photoaging. In contrast to the mechanism of short-term exposure, the mechanism underlying the effects of long-term exposure on the skin has been well studied: UV radiation exposure over a long period of time produces high levels of reactive oxygen species (ROS), which attack immunopathologically mediated cells (natural killer cells, dendritic cells, T cells, and B cells) by damaging the DNA [5-8].

When the eyes are exposed to UV radiation, the cornea becomes painfully inflamed and induces hyperemia of the eye $[9,10]$. The lens of the eye can be chronically damaged by longterm exposure to UV radiation, becoming cloudy with cataracts. Regarding the mechanism of UV exposure-induced cataracts, the waste material lipofuscin accumulates in the retina due to UV radiation. This accumulation induces the production of singlet oxygen, which exerts oxidative stress on the lens. The singlet oxygen induces the destruction and denaturation of collagen, a structural component of the lens. In this manner, the ROS generated by UV radiation are the main cause of UV exposure-induced cataracts. Long-term UV exposure of the eye can also induce age-related macular degeneration (AMD) [11, 12].

In an earlier paper, we reported that inducible nitric oxide synthase (iNOS) and photoaging, which is induced by long-term UVA eye irradiation, are closely related [13]. In addition, although there is a close relationship between long-term UVA irradiation and retinal denaturation, the relationship to iNOS is not known. In the present study, we aimed to clarify the mechanism underlying the onset of the retinal denaturation induced by long-term UVA eye irradiation based on iNOS.

\section{Methods}

\section{Animal Experiments}

Specific-pathogen-free 8-week-old male C57BL/6j mice (SLC, Hamamatsu, Japan) and C57BL/6j iNOS knockout (iNOS ${ }^{-/}$) mice (Jackson Laboratories, Bar Harbor, ME, USA) were used for the experiments. The difference between C57BL/6j mice and control iNOS ${ }^{-/-}$mice had no effect on the results [14]. The mice were kept individually in cages in an air-conditioned room at $23 \pm 1{ }^{\circ} \mathrm{C}$ and an a 12-h light-dark cycle. The study was carried out in strict accordance with the recommendations of the guide for the care and use of laboratory animals of Suzuka University of Medical Science (approval number: 34). There were 12 mice per group. UVA irradiation was performed as described in a previous study [15]. Briefly, the eyes were irradiated with UVA at a dose of $110 \mathrm{~kJ} / \mathrm{m}^{2}$ using the FL20SBLB-A lamp (wavelength, 300-400 nm; peak emission, $352 \mathrm{~nm}$; Toshiba Co., Tokyo, Japan). The UVA light was filtered through a glass filter to block UVB rays. As the time of radiation, we covered the skin with aluminum foil, except for the eye. The control group received irradiation to the eyes with visible light (wavelength, 400-700 nm). Exposure was performed 3 times a week over a 1-year period from 8 weeks of age. All of the surgeries were performed under pentobarbital anesthesia, and all efforts were made to minimize suffering. In addition, photoaging was induced in this test condition (Fig. 1). 

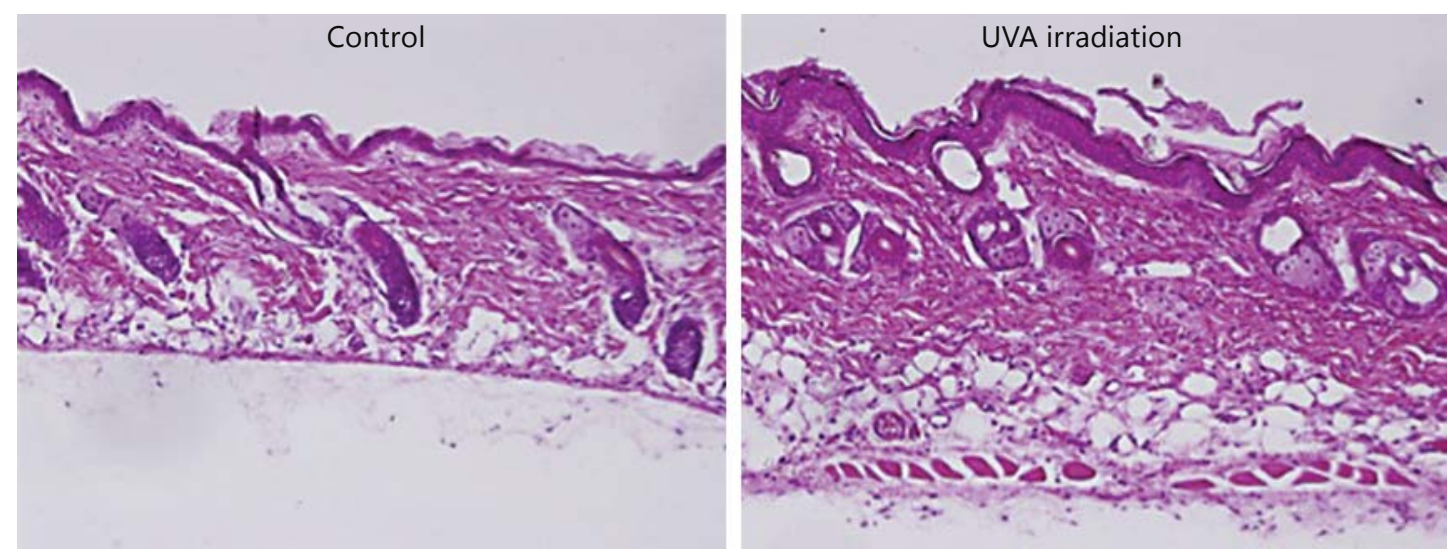

Fig. 1. Effects of long-term ultraviolet A (UVA) eye irradiation on the skin. One year after the irradiation of the eyes of C57BL/6j mice, skin specimens were obtained, fixed with $10 \%$ formalin, and embedded in paraffin. Thin sections of the skin specimens were stained with hematoxylin-eosin.

\section{Clodronate Liposomes (Neutralizing) Treatment}

One of the factors associated with the retina is the accumulation of macrophages. Therefore, we used clodronate liposomes as macrophage inhibitors. Approximately $200 \mu \mathrm{L}$ of clodronate liposomes (macrophage inhibitor, clodronate disodium $7 \mathrm{mg} / \mathrm{mL}$; FormuMax Scientific Inc., Palo Alto, CA, USA) in saline was injected intraperitoneally into the non-control mice once a week for 12 months [16]. Saline alone (200 $\mu \mathrm{L})$ was injected into the control mice.

\section{Preparation and Staining of the Eyes}

The mice were sacrificed $6 \mathrm{~h}$ after the final exposure for histological study. The eye specimens were fixed in phosphate-buffered paraformaldehyde (4\%) and cut into 5 - $\mu$ m-thick sections. The eye specimens were stained with hematoxylin-eosin (HE) in accordance with the standard procedure.

For the analysis of $\beta$-amyloid expression, the eye sections were stained with Congo red stain $6 \mathrm{~h}$ after the final exposure in accordance with the standard procedure. We used a polarizing microscope for all observations.

\section{Isolation of Retina Samples}

For Western blot analysis, we isolated only the retina from the ophthalmus. The retina samples were homogenized in lysis buffer (Kurabo, Osaka, Japan) supplemented with protease inhibitor cocktail (Nakarai Tesque, Kyoto, Japan) and centrifuged at 14,000 $\mathrm{g}$ for $30 \mathrm{~min}$. The supernatant of the retina was extracted and kept at $-80^{\circ} \mathrm{C}$ until analysis.

\section{Western Blot Analysis}

We performed Western blot analysis as previously described [17]. Briefly, the supernatant samples of the retina (equal amounts of protein samples) were loaded onto a BIS-TRIS Blot Gel (Life Technologies, Carlsbad, CA, USA) and electrophoresed. Following separation, the proteins were transferred to a nitrocellulose membrane and incubated with $5 \%$ skimmed milk at $4^{\circ} \mathrm{C}$ overnight. After blocking, the membranes were incubated at $25^{\circ} \mathrm{C}$ for $1 \mathrm{~h}$ with primary antibodies against iNOS (1:1,000; Santa Cruz Biotechnology Inc., Santa Cruz, CA, USA), matrix metalloproteinase-2 (MMP-2) (1:1,000; Bioss Inc., Woburn, MA, USA), MMP-9 (1:1,000; Abnova Co., Taipei, Taiwan), vascular endothelial growth factor (VEGF) $(1: 1,000$; 


\section{Biomenticicine 紏㑔b}

Fig. 2. Long-term ultraviolet $A$ (UVA) eye irradiation induced retinal damage in $\mathrm{C} 57 \mathrm{BL} / 6 \mathrm{j}$ mice. a Macroscopic eye examination. $\mathbf{b}$ The eye specimens were stained with hematoxylin-eosin. The degenerated cells with vacuoles in the retinal pigment epithelium layer are shown (short arrows). Scale bar, $100 \mu \mathrm{m}$.
Biomed Hub 2017;2:453542 (DOI: 10.1159/000453542)

(C) 2017 The Author(s). Published by S. Karger AG, Base www.karger.com/bmh

Hiramoto et al.: Long-Term Ultraviolet A Eye Irradiation Causes Retina Denaturation in Mice

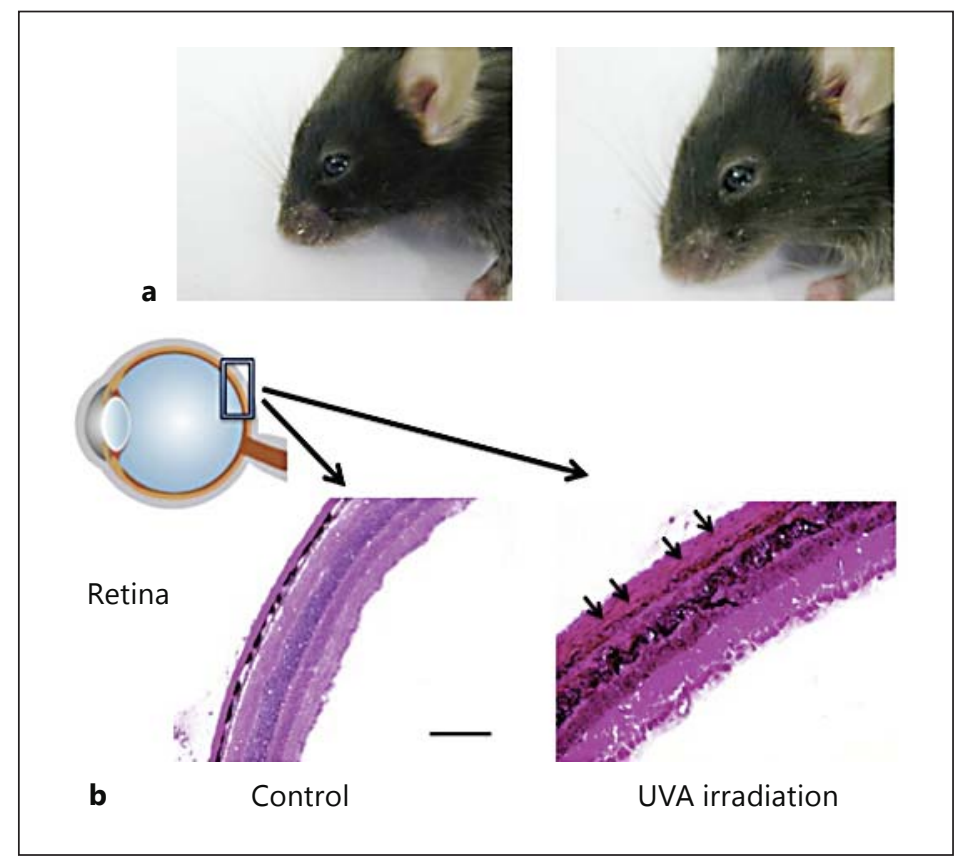

Abnova Co.), macrophages (F4/80, 1:1,000; Bio-Rad, Raleigh, NC, USA), $\beta$-amyloid (1:1,000; Rockland Immunochemicals Inc., Gilbertsville, PA, USA), and $\beta$-actin (1:5,000; Sigma-Aldrich, St. Louis, MO, USA). Bands on the membranes were visualized using a horseradish peroxidase-conjugated secondary antibody (Life Technologies, Frederick, MD, USA) and ImmunoStar Zeta reagent (Wako, Osaka, Japan). Images were acquired using the Multi-Gauge Software program (Fujifilm, Greenwood, SC, USA).

\section{Statistical Analysis}

Results are reported as means \pm standard deviation. For comparisons among groups, the Student $t$ test was applied, with $p$ values $<0.05$ considered to be statistically significant.

\section{Results}

\section{Effect of UVA Irradiation on the Eyes in C57BL/6j Mice}

Under pentobarbital anesthesia, the eyes were irradiated topically with UVA 3 times a week for 12 months for $1 \mathrm{~h}$ per day, and the eye specimens were obtained after the last UVA irradiation session. No obvious changes were observed in the macroscopic evaluation of the surface of the eyes (Fig. 2a). However, examination of HE-stained retina specimens showed that chronic UVA radiation exposure resulted in an increased number of degenerated cells with vacuoles in the retinal pigment epithelium (RPE) layer in the exposed mice compared to unexposed control mice (Fig. 2b).

\section{Expression of iNOS, MMP-2, MMP-9, Macrophages, and VEGF in the Retina of C57BL/6j}

Mice

In order to analyze the factors associated with AMD in the UVA-irradiated mice, we investigated the expressions of iNOS, MMP-2, MMP-9, macrophages, and VEGF in the retina by Western blot analysis (Fig. 3). In the 12-month-old mice, the expression levels of iNOS, MMP-2, 

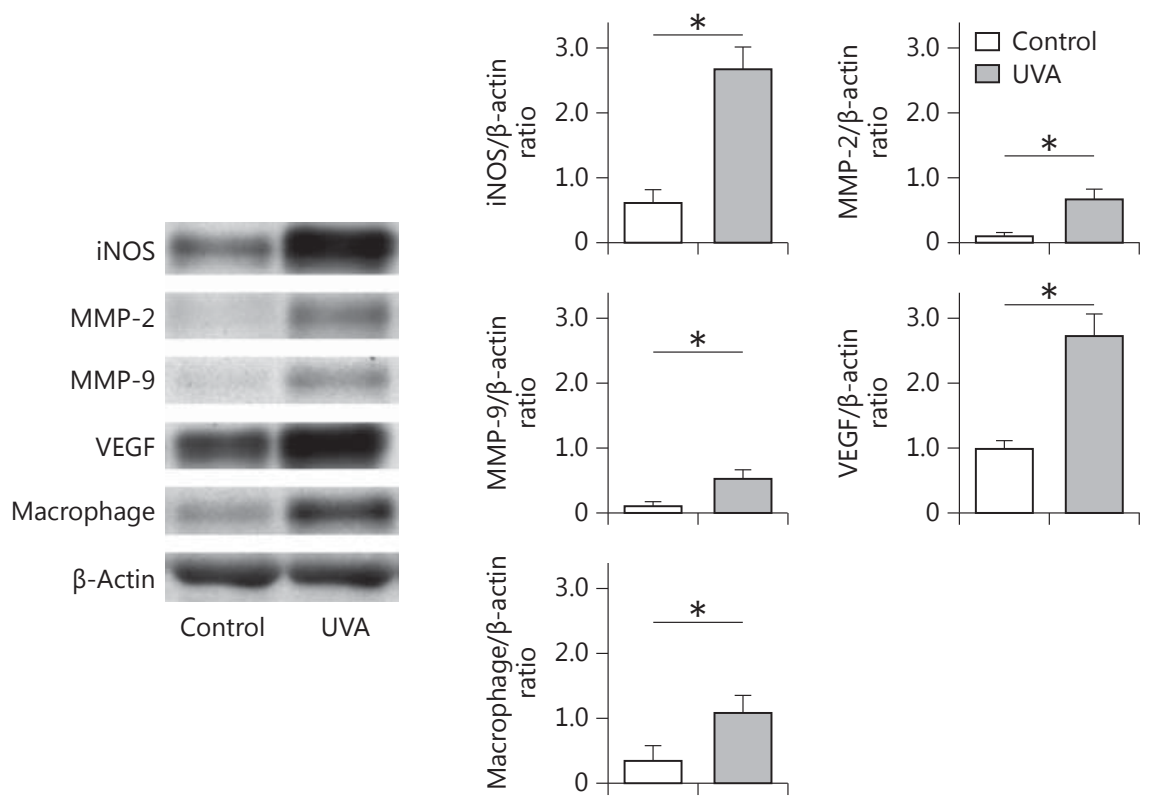

Fig. 3. Effects of long-term ultraviolet A (UVA) eye irradiation on the expression of inducible nitric oxide synthase (iNOS), matrix metalloproteinase-2 (MMP-2), MMP-9, vascular endothelial growth factor (VEGF), and macrophages in C57BL/6j mice. Values are expressed as mean \pm SD derived from 12 animals. ${ }^{*} p<0.05$.

MMP-9, macrophages, and VEGF were increased remarkably in the UVA-irradiated mice compared to the controls.

Expression of $\beta$-Amyloid in the Retina of C57BL/6j Mice

Given that $\beta$-amyloid has been implicated as a cause of AMD in recent years, we examined its expression in the irradiated mice by Congo red-stained samples and Western blot analysis. The expression of $\beta$-amyloid in the retina was increased in the UVA-irradiated mice compared with the control mice (Fig. 4).

\section{Effects of UVA Irradiation on the Eyes in iNOS ${ }^{-/-}$Mice}

Under pentobarbital anesthesia, the eye was irradiated topically with UVA 3 times a week for 12 months for $1 \mathrm{~h}$ per day, and the retina specimens were obtained after the last UVA irradiation session. Surprisingly, no obvious damage due to UVA irradiation was observed in the HE-stained retina specimens of iNOS $^{-/-}$mice (Fig. 5a). Furthermore, while $\beta$-amyloid expression was higher in the retinas of the UVA-irradiated C57BL/6j mice than in those of the control mice (Fig. 4), no marked difference in expression was noted between the UVA-irradiated $\mathrm{iNOS}^{-/-}$mice and the control mice (Fig. 5b).

\section{Effect of UVA Irradiation on the Retina of C57BL/6j Mice after Clophosome Injection}

One of the causes of AMD is the increase in macrophage expression. Thus, we next examined retinal damage using a macrophage inhibitor. Under pentobarbital anesthesia, the eye was irradiated topically with UVA 3 times a week for 12 months for $1 \mathrm{~h}$ per day, and clodronate liposomes (macrophage inhibitor) were injected intraperitoneally into the mice 


\section{Bilomellicicine

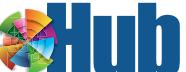

Fig. 4. Effects of long-term ultraviolet A (UVA) eye irradiation on the expression of $\beta$-amyloid in the retinas of $\mathrm{C} 57 \mathrm{BL} / 6 \mathbf{j}$ mice. a Thin sections of the eye specimens were stained with Congo red. Scale bar, $100 \mu \mathrm{m}$. b Expression of $\beta$-amyloid in the retina by Western blot analysis. Values are expressed as mean \pm SD derived from 12 animals. ${ }^{*} p<0.05$.
Biomed Hub 2017;2:453542 (DOI: 10.1159/000453542)

(C) 2017 The Author(s). Published by S. Karger AG, Basel www.karger.com/bmh

Hiramoto et al.: Long-Term Ultraviolet A Eye Irradiation Causes Retina Denaturation in Mice

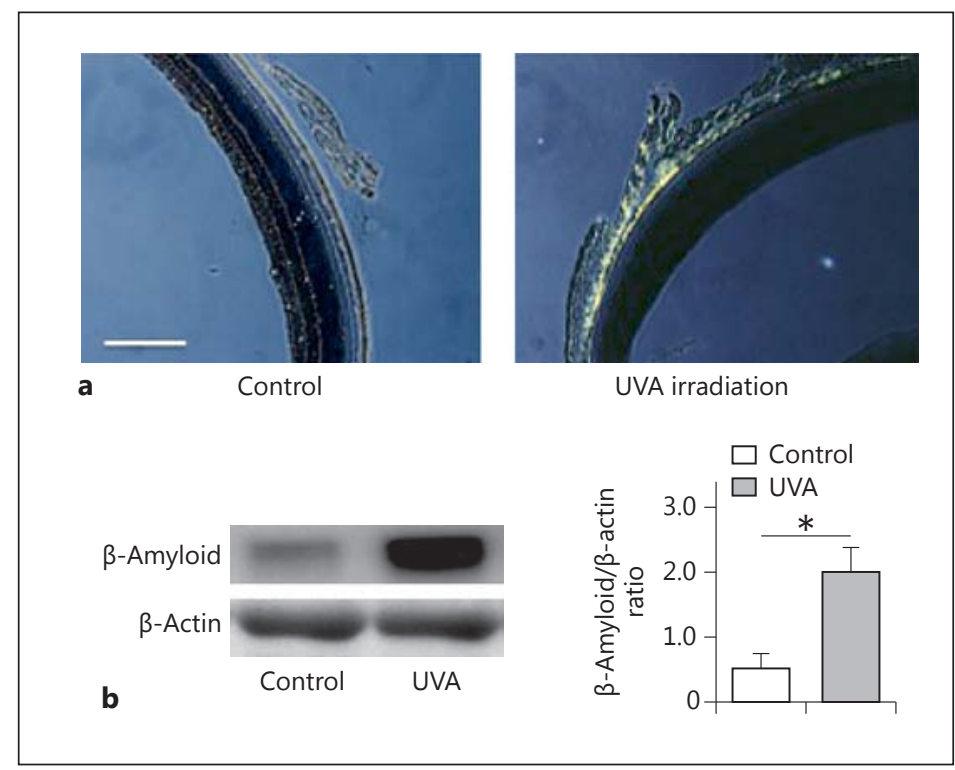

once a week for 12 months. The retina specimens were obtained after the last UVA irradiation session. The examination of HE-stained retina specimens showed that the damage to the retina by UVA irradiation plus Clophosome injection was increased compared to that of the unexposed retina, but it was not markedly different from the findings in mice exposed to UVA irradiation alone (Fig. 6a). The $\beta$-amyloid expression by Western blot analysis was markedly higher in the retinas of the UVA plus Clophosome-treated mice than in the control mice and was increased compared with the mice exposed to UVA irradiation alone. The expression of VEGF was increased in the UVA plus Clophosome-treated mice compared with the controls, but it was not markedly different from the findings in the mice exposed to UVA irradiation alone (Fig. 6b). In addition, the expression levels of iNOS, MMP-2, and MMP-9 in the UVAirradiated mice were increased in comparison to controls; however, the expression levels of UVA-irradiated mice and UVA plus Clophosome-treated mice were similar.

\section{Discussion}

In this study, the damage and expression of iNOS, MMP-2, MMP-9, VEGF, macrophages, and $\beta$-amyloid in the retina increased by long-term UVA eye irradiation. Furthermore, in iNOS $^{-/-}$mice, this increased damage as well as MMP-2, MMP-9, VEGF, macrophage, and $\beta$-amyloid expression were suppressed.

MMP-2, MMP-9, and VEGF expression in the retina is increased by light radiation, subsequently inducing the development of AMD $[18,19]$. With regard to the mechanism, the levels of ROS are increased by photic (or UV) stimulation, which causes an inflammatory reaction and vascularization by VEGF. ROS also induce increased levels of MMP-2 and MMP-9, which causes degradation of the extracellular matrix necessary for the progress of vascularization. In this study, we observed an increased expression of MMP-2, MMP-9, and VEGF following UVA irradiation, just as seen with AMD (Fig. 1, 2).

In recent years, the relationship between retina disorders and $\beta$-amyloid levels has been examined. The $\beta$-amyloid appearing in the retina is increased by physical stress etc. The increased $\beta$-amyloid produces drusen to derive and induce AMD. Thus, $\beta$-amyloid is frequently 


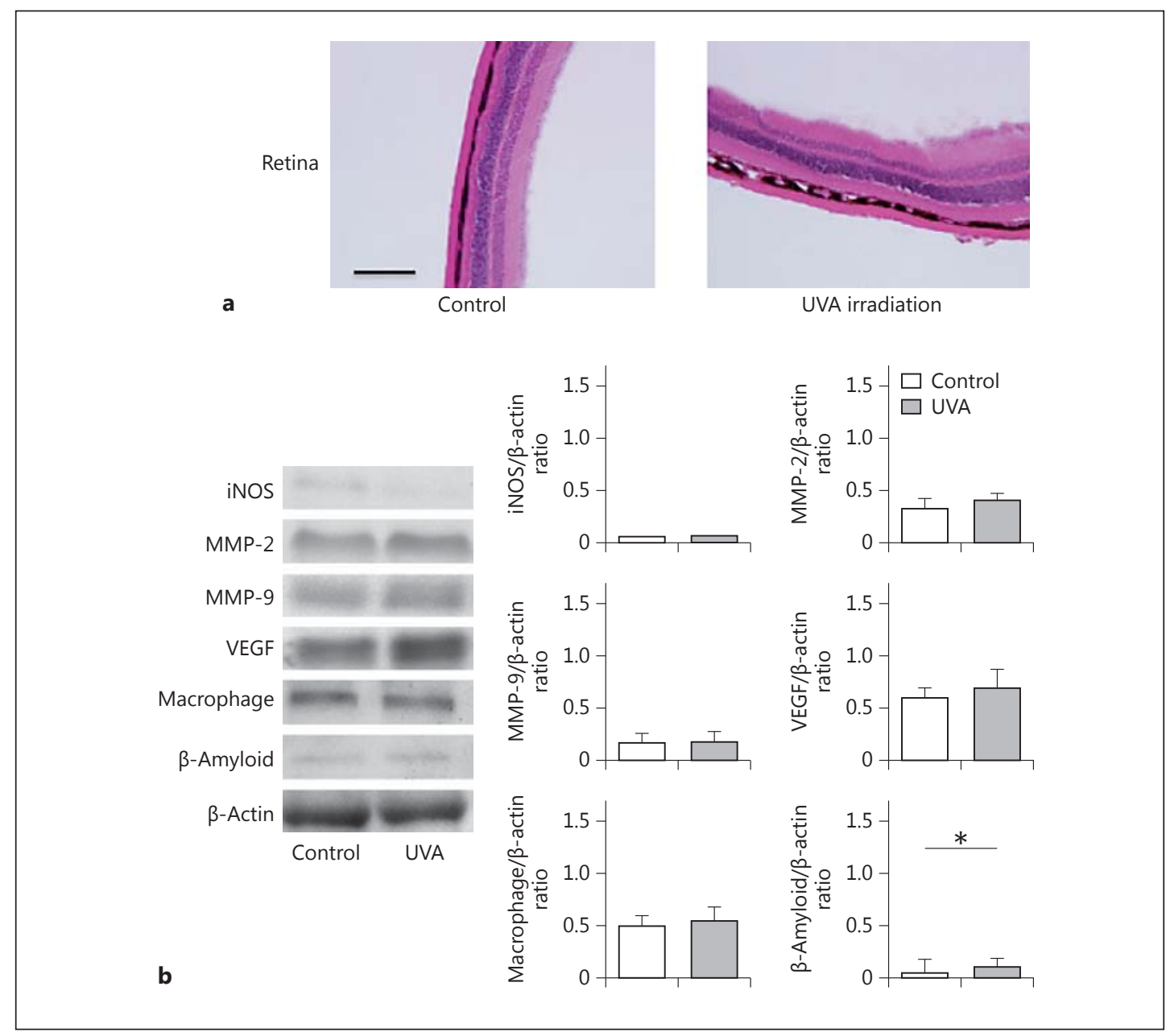

Fig. 5. Long-term ultraviolet A (UVA) eye irradiation induced retinal damage (a) and the expression of inducible nitric oxide synthase (iNOS), matrix metalloproteinase-2 (MMP-2), MMP-9, vascular endothelial growth factor (VEGF), macrophages, and $\beta$-amyloid (b) in iNOS knockout mice. Thin sections of the eye specimens were stained with hematoxylin-eosin. Scale bar, $100 \mu \mathrm{m}$. Values are expressed as mean \pm SD derived from 12 animals. $* p<0.05$.

expressed in AMD patients' retinas [20-22]. Furthermore, cultured RPE cells showed elevated expression of VEGF as well as $\beta$-amyloid [23]. The production reinforcement action in RPE cells by $\beta$-amyloid is the activation of NF- $\kappa \beta$ receptor for advanced glycation end products (AGEs), which is a receptor for AGEs (RAGE) produced by aging [24]. This marked increase in the levels of AGEs and the immunological activity of RAGE are apparent in the RPE and visible cells in AMD patients [24]. Beta-amyloid subsequently reduces the visual performance in AMD patients by denaturation of the RPE and/or visible cells through RAGE. Our findings in the present study further suggest that VEGF might contribute to the genesis of choroidal neovascularization and the sthenia of vascular permeability.

We also observed increased expression of iNOS in this experiment. UV radiation is known to induce such an increase $[14,25]$. While increased $\beta$-amyloid expression was observed in the retinas of the control mice, no increase in $\beta$-amyloid or VEGF expression was noted in the iNOS $^{-/-}$mice, and the retina damage was reduced (Fig. 4). These results suggest that iNOS may be involved in AMD of $\beta$-amyloid origin in long-term UVA-irradiated mice. Although 


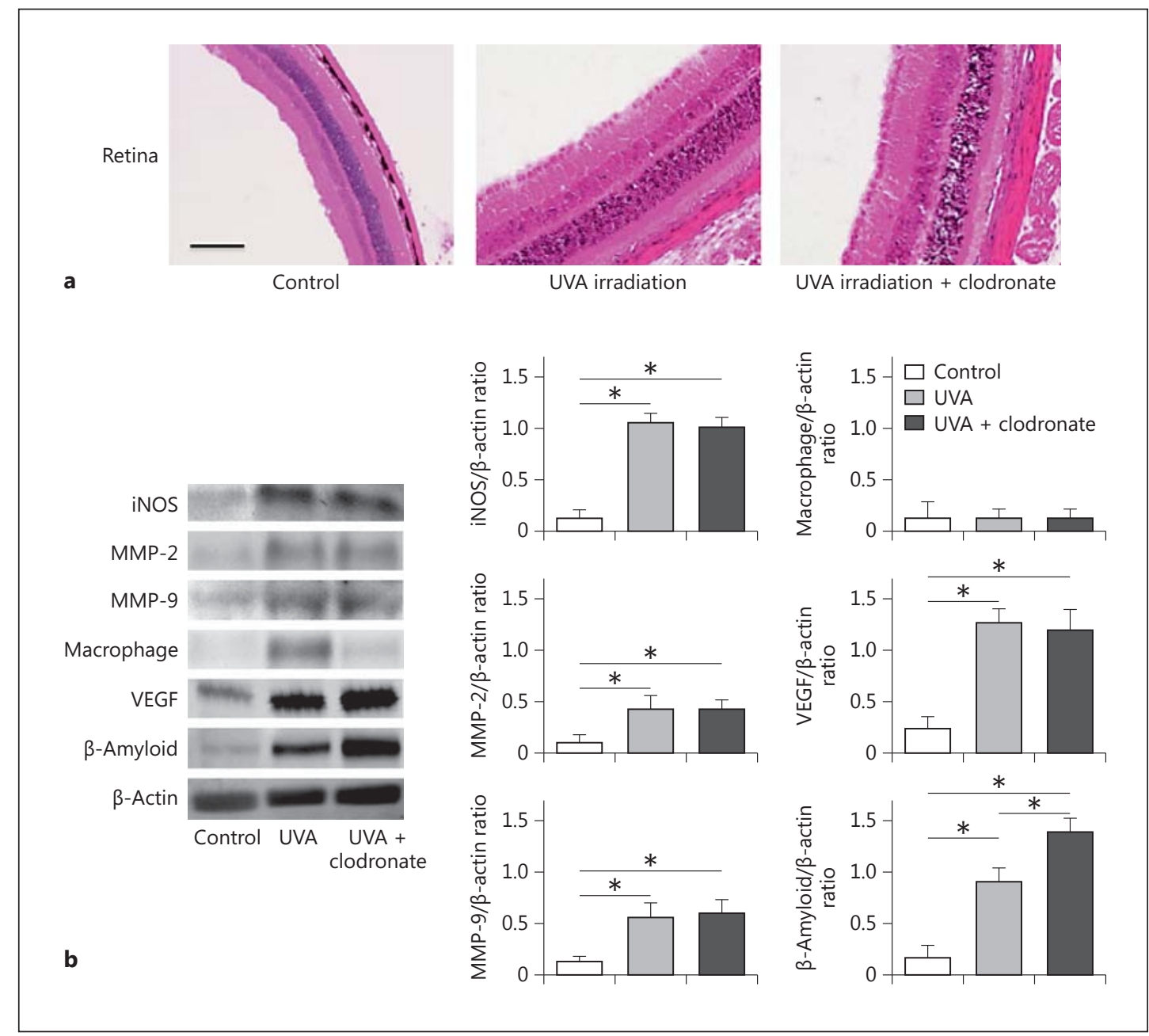

Fig. 6. Long-term ultraviolet A (UVA) eye irradiation induced retinal damage (a) and increased expression of macrophages, vascular endothelial growth factor (VEGF), and $\beta$-amyloid (b) in Clophosome-treated C57BL/6j mice. Thin sections of the eye specimens were stained with hematoxylin-eosin. Scale bar, $100 \mu \mathrm{m}$. Values are expressed as mean \pm SD derived from 12 animals. ${ }^{*} p<0.05$. iNOS, inducible nitric oxide synthase; MMP-2, matrix metalloproteinase-2; MMP-9, matrix metalloproteinase-9.

there have been many reports that $\beta$-amyloid is involved in the expression of iNOS [26,27], none have reported the converse, namely that iNOS is involved in the expression of $\beta$-amyloid. We previously reported that gp91phox was involved in the expression of $\beta$-amyloid [28]. Therefore, while we do suspect that iNOS may have increased the expression of $\beta$-amyloid through gp91phox, further examinations will be necessary to confirm these findings.

In a previous study, we reported that long-term UVA eye irradiation caused accumulation of $\beta$-amyloid in the hippocampus of the mouse brain [28]. In addition, Suzuki and colleagues reported that $\beta$-amyloid causes neurodegenerative effects and is expressed in both the hippocampus and the retina [29-31]. Alzheimer patients often suffer from AMD [20-22]. Given the above, increased expression of $\beta$-amyloid in the hippocampus and the retina due to long-term UVA irradiation may be a risk factor for Alzheimer disease and AMD. However, further studies will be necessary to clarify the relationship between long-term UVA eye irradiation and the iNOS// $\beta$-amyloid system. 
Several studies have reported that photooxidative stress causes the oxidative phosphorylation of phospholipids, which induce a continual increase in MCR-1 expression and macrophage production [32-34]. Macrophages increase the expression of VEGF and induce vascularization in the retina [32-34]. Furthermore, in the retina, while macrophages perform the introjection of $\beta$-amyloid and prevent the onset of Alzheimer disease, the mass release of inflammatory cytokines is achieved by the introjection of $\beta$-amyloid [35]. Given the above, we examined the effects of the prolonged administration of clodronate liposomes, a macrophage inhibitor, on retina degeneration in the present study. While $\beta$-amyloid expression was markedly increased by the administration of clodronate liposomes (Fig. 5), VEGF expression remained unaffected (Fig. 5b). As described in a previous report [35], the macrophages removed the $\beta$-amyloid from the retina, subsequently increasing the secretion of inflammatory cytokines and active oxygen. We therefore concluded that $\beta$-amyloid and macrophages influenced each other mutually and were both involved in the denaturation of the retina.

In addition, VEGF plays an important role in retina damage. These results suggest that although vascularization was affected by iNOS, which was induced by long-term UVA eye irradiation, it was shown that it was not influenced by macrophages. Although it was thought that VEGF and macrophages act separately, the relationship between VEGF and long-term UVA eye irradiation remains to be fully elucidated.

In this study, the expression of iNOS, $\beta$-amyloid, and macrophages was increased by longterm UVA eye irradiation, suggesting that all three acted mutually and in concert to cause AMD-like damage. We therefore concluded that prophylactic treatment of AMD-like damage and the clarification of the role of iNOS, $\beta$-amyloid, and macrophages in the onset of AMD-like damage due to long-term UVA eye irradiation are needed.

\section{Acknowledgments}

This work was supported by JSPS KAKENHI Grant No. 90251793.

\section{Disclosure Statement}

The authors declare that they have no conflicts of interest concerning this article.

\section{References}

1 Danno K, Horio T: Sunburn cell: factors involved in its formation. Photochem Photobiol 1987;45:683-690.

-2 Kripke ML, Fischer MS: Immunologic parameters of ultraviolet carcinogenesis. J Natl Cancer Inst 1976;57: 211-215.

- 3 Toews GB, Bergstresser PR, Streilein JW: Epidermal Langerhans cell density determines whether contact hypersensitivity or unresponsiveness follows skin painting with DNFB. J Immunol 1980;124:445-453.

4 Araneo BA, Dowell T, Moon HB, Daynes RA: Regulation of murine lymphokine production in vivo. Ultraviolet radiation exposure depresses IL-2 and enhances IL-4 production by T cells through an IL-1-dependent mechanism. J Immunol 1989;143:1737-1744.

5 Gilchrest BA: Skin aging and photoaging: an overview. J Am Acad Dermatol 1989;21:610-613.

6 Lavker RM: Structural alterations in exposed and unexposed aging skin. J Invest Dermatol 1979;73:59-66.

7 Fisher GJ, Wang ZQ, Datta SC, Varani J, Kang S, Voorhees JJ: Pathophysiology of premature skin aging induced by ultraviolet light. N Engl J Med 1997;337:1419-1428.

-8 Hong YF, Lee HY, Jung BJ, Jang S, Chung DK, Kim H: Lipoteichoic acid isolated from Lactobacillus plantarum down-regulates UV-induced MMP-1 expression and up-regulates type 1 collagen through the inhibition of reactive oxygen species generation. Mol Immunol 2015;67:248-255. 
-9 Cejkova J, Cejka C, Ardan T, Sirc J, Michalek J, Luyckx J: Reduced UVB-induced corneal damage caused by reactive oxygen and nitrogen species and decreased changes in corneal optics after trehalose treatment. Histol Histopathol 2010;25:1403-1416.

10 Young AR: Acute effects of UVR on human eyes and skin. Prog Biophys Mol Biol 2006;92:80-85.

-11 Kraljevic Pavelic S, Klobucar M, Sedic M, Micek V, Gehrig P, Grossman J, Pavelic K, Vojnikvic B: UV-induced retinal proteome changes in the rat model of age-related macular degeneration. Biochim Biophys Acta 2015; 1852:1833-1845.

12 Yam JC, Kwok AK: Ultraviolet light and ocular diseases. Int Ophthalmol 2014;34:383-400.

13 Hiramoto K, Yamate Y, Kobayashi H, Ishii M: Long-term ultraviolet A irradiation of the eye induces photoaging of the skin in mice. Arch Dermatol Res 2012;304:39-45.

14 Hiramoto K, Yanagihara N, Sato EF, Inoue M: Ultraviolet B irradiation of the eye activates a nitric oxidedependent hypothalamopituitary proopiomelanocortin pathway and modulates functions of alpha-melanocyte-stimulating hormone-responsive cells. J Invest Dermatol 2003;120:123-127.

15 Hiramoto K, Jikumaru M, Yamate Y, Sato EF, Inoue M: Ultraviolet A irradiation of the eye induces immunomodulation of skin and intestine in mice via hypothalamo-pituitary-adrenal pathways. Arch Dermatol Res 2009;301:239-244.

16 Fu CL, Odegaard JI, Hsieh MH: Macrophages are required for host survival in experimental urogenital schistosomiasis. FASEB J 2015;29:193-207.

17 Yokoyama S, Hiramoto K, Koyama M, Ooi K: Impaired skin barrier function in mice with colon carcinoma induced by azoxymethane and dextran sodium sulfate. Biol Pharm Bull 2015;38:947-950.

-18 Liutkeviciene R, Lesauskaite V, Sinkunaite-Marsalkiene G, Zaliuniene D, Zaliaduonyte-Peksiene D, Mizariene V, Gustiene O, Jasinskas V, Jariene G, Tamosiunas A: The role of matrix metalloproteinases polymorphisms in age-related macular degeneration. Ophthalmic Genet 2015;36:149-155.

-19 Lee HS, Jun JH, Jung EH, Koo BA, Kim YS: Epigalloccatechin-3-gallate inhibits ocular neovascularization and vascular permeability in human retinal pigment epithelial and human retinal microvascular endothelial cells via suppression of MMP-9 and VEGF activation. Molecules 2014;19:12150-12172.

20 Johnson LV, Leitner WP, Rivest AJ, Staples MK, Radeke MJ, Anderson DH: The Alzheimer's A beta-peptide is deposited at sites of complement activation in pathologic deposits associated with aging and age-related macular degeneration. Proc Natl Acad Sci USA 2002;99:11830-11835.

-21 Anderson DH, Talaga KC, Rivest AJ, Barron E, Hageman GS, Johnson LV: Characterization of beta amyloid assemblies in drusen: the deposits associated with aging and age-related macular degeneration. Exp Eye Res 2004; 78:243-256.

22 Dentchev T, Milam AH, Lee VM, Trojanowski JQ, Dunaief JL: Amyloid-beta is found in drusen from some agerelated macular degeneration retinas, but not in drusen from normal retinas. Mol Vis 2003;9:184-190.

-23 Ma W, Lee SE, Guo J, Qu W, Hudson BI, Schmidt AM, Barile GR: RAGE ligand upregulation of VEGF secretion in ARPE-19 cells. Invest Ophthalmol Vis Sci 2007;48:1355-1361.

24 Howes KA, Liu Y, Dunaief JL, Milam A, Frederick JM, Marks A, Baehr W: Receptor for advanced glycation end products and age-related macular degeneration. Invest Ophthalmol Vis Sci 2004;45:3713-3720.

25 Panich U, Tangsupa-a-nan V, Onkoksoong T, Kongtaphan K, Kasetsinsombat K, Akarasereenont P, Wongkajornsilp A: Inhibition of UVA-mediated melanogenesis by ascorbic acid through modulation of antioxidant defense and nitric oxide system. Arch Pharm Res 2011;34:811-820.

26 Zeng C, Lee JT, Chen H, Chen S, Hsu CY, Xu J: Amyloid-beta peptide enhances tumor necrosis factor-alpha-induced iNOS through neutral sphingomyelinase/ceramide pathway in oligodendrocytes. J Neurochem 2005;94:703-712.

-27 Akama KT, van Eldik LJ: $\beta$-Amyloid stimulation of inducible nitric-oxide synthase in astrocytes is interleukin- $1 \beta$ and tumor necrosis factor- $\alpha$ (TNF $\alpha$ )-dependent, and involves a TNF $\alpha$ receptor-associated factor-and NFK $\beta$ inducing kinase-dependent signaling mechanism. J Biol Chem 2000;275:7918-7924.

28 Hiramoto K, Kasahara E: Long-term UVA eye irradiation causes decreased learning ability in mice. Photodermatol Photoimmunol Photomed 2016;32:129-135.

-29 Suzuki M, Tsujikawa M, Itabe H, Du ZJ, Xie P, Matsumura N, Fu X, Zhang R, Sonoda K, Egashira K, Hazen S, Kamei M: Chronic photo-oxidative stress and subsequent MCP-1 activation as causative factors for age-related macular degeneration. J Cell Sci 2012;125:2407-2415.

30 Suzuki M, Kamei M, Itabe H, Yoneda K, Bando H, Kume N, Tano Y: Oxidized phospholipids in the macula increased with age and in eyes with age-related macular degradation. Mol Vis 2007;13:772-778.

-31 Kamei M, Yoneda K, Kume N, Suzuki M, Itabe H, Matsuda K, Shimaoka T, Minami M, Yonehara S, Kita T, Kinoshita S: Scavenger receptors for oxidized lipoprotein in age-related macular degeneration. Invest Ophthalmol Vis Sci 2007;48:1801-1807.

-32 Blanks JC, Torigoe Y, Hinton DR, Blanks RH: Retinal degeneration in the macula of patients with Alzheimer's disease. Ann NY Acad Sci 1991;640:44-46.

-33 Blanks JC, Hinton DR, Sadun AA, Miller CA: Retinal ganglion cell degeneration in Alzheimer's disease. Brain Res 1989; 501:364-372.

34 Sadun AA, Bassi CJ: Optic nerve damage in Alzheimer's disease. Ophthalmology 1990;97:9-17.

-35 Masters SL, Dunne A, Subramanian SL, Hull RL, Tannahill GM, Sharp FA, Becker C, Frenchi HL, Yoshihara E, Chen Z, Mullooly N, Mielke LA, Harris J, Coll RC, Mills KHG, Mok KH, Mewsholme P, Nunez G, Yodoi J, Kahn SE, Lavelle EC, O'Neill LAJ: Activation of the NLRP3 inflammasome by islet amyloid polypeptide provides a mechanism for enhanced IL-1 $\beta$ in type 2 diabetes. Nat Immunol 2010;11:897-904. 